\title{
Obezite Farkındalığı ve İçgörü Ölçeği: Geçerlilik ve Güvenilirlik Çalışması
}

\section{The Obesity Awareness and Insights Scale: Validity and Reliability Study}

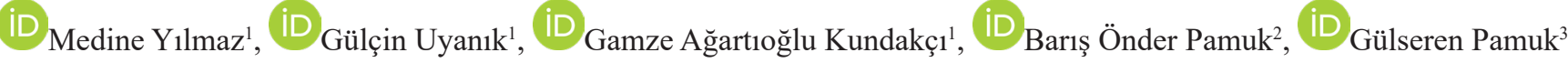

${ }^{1}$ İzmir Katip Çelebi Üniversitesi Sağlık Bilimleri Fakültesi Hemşirelik Bölümü Halk Sağlığı Hemşireliği Anabilim Dalı

${ }^{2}$ İzmir Katip Çelebi Üniversitesi Atatürk Eğitim ve Araştırma Hastanesi Endokrinoloji ve Metabolizma Hastalıkları Anabilim Dalı

${ }^{3}$ İzmir Katip Çelebi Üniversitesi Atatürk Eğitim ve Araştırma Hastanesi Aile Hekimliği Anabilim Dalı

Öz

Amaç: Obezite Farkındalığı ve İçörü Ölçeğinin (OFI Ölçeği) (OASIS: The Obesity Awareness and Insight Scale) Türkçeye ve Türk kültürüne uyarlanarak geçerlilik ve güvenirlik çalışmalarının yapılmasıdır.

Gereç ve yöntem: Metodolojik tipteki bu araştırma bir eğitim ve araştırma hastanesinin endokrinoloji ve metabolizma hastalıkları polikliniği ile bir eğitim aile sağlığı merkezinde yürütülmüştür. Araştırma örneklemini bu birimlere başvuruda bulunan165 fazla kilolu/obez birey oluşturmuştur. Veriler Görüşme Formu ve "Obezite Farkındalığı ve İçgörü Ölçeği (OFI)" (www.illnessawarenessscales.com) ile toplanmıştır. Ölçeğin geçerlilik analizleri "Kapsam Geçerlilik İndeksi, Açımlayıcı Faktör Analizi” ile, güvenilirlik analizleri "değişmezlik, iç tutarlılık ve madde toplam puan korelasyonu” ile yapılmıştır.

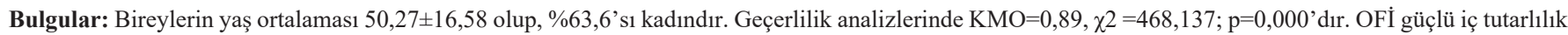
(Cronbach alpha 0,86), test tekrar test güvenilirliği $(0,79)$ göstermiştir. Madde toplam korelasyonu değerleri 0,428-0,746 arasında değişmektedir. Açımlayıcı faktör analizine göre ölçek tek boyutludur. OFİ toplam puan ortalaması $6,87 \pm 2,48$ olup, bireylerin obezite farkındalıklarının ortanın üstünde olduğu belirlenmiştir.

Sonuç: Obezite Farkındalığı ve İçgörü Ölçeği, fazla kilolu/ obez bireylerin obezite farkındalıklarını belirlemek amacıyla kullanılabilecek geçerli ve güvenilir bir ölçme aracıdır.

Anahtar kelimeler: Obezite, obezite farkındalı̆̆ı, geçerlilik, güvenirlik

Abstract

Objective: The aim of this study is to adapt the Obesity Awareness and Insight (OASIS) to Turkish and Turkish culture and to conduct validity and reliability studies.

Material and methods: This methodological research was carried out in an education and research hospital endocrinology and metabolic diseases polyclinic and in an education family health center. The research sample consisted of 165 overweight / obese individuals applying to these units. Data were collected by Interview Form and "Obesity Awareness and Insight Scale". Validity analyzes of the scale were made with "Content Validity Index, Exploratory Factor Analysis" and reliability analyzes were made with "test-retest reliability, internal consistency and item total correlation".

Results: The average age of individuals is $50.27 \pm 16.58$ and $63.6 \%$ of them are women. In validity analysis, KMO $=0.89, \chi 2=468,137 ; p=0.000$. The OASIS showed strong internal consistency (Cronbach alpha 0.86 ), test-retest reliability $(0.79)$. Item total correlation values ranged from $0.428-0.746$. According to exploratory factor analysis, the scale is single latent component. The total mean score of the OASIS is $6.87 \pm 2.48$, and the obesity awareness of individuals is above the middle.

Conclusion: The Turkish form of the Obesity Awareness and Insight Scale is a valid and reliable measurement tool that can be used to determine the obesity awareness of overweight / obese individuals.

Key words: Obesity, obesity awareness, validity, reliability

Yazışma Adresi: Gülçin Uyanık, Balatçık mh. Havaalanı Şosesi İzmir Kâtip Çelebi Üniversitesi Sağlık Bilimleri Fakültesi, Çiğli/İzmir.

E-Posta: gulcinyelten@hotmail.com

Alınma Tarihi: 11.04.2020 / Kabul Tarihi: 19.11.2020 / Yayımlanma Tarihi: 20.09.2021

Obezite farkındalı̆̆ 1 ve içgörü ölçeği - Y1lmaz ve ark.

Genel Tip Derg 2021;31(3)196-201 


\section{Giriş}

Obezite, yıkıcı sonuçları ile mortalitede artışa neden olan 20'den fazla kronik hastalık ve sağlık durumu ile önemli ölçüde ilişkili günümüzün en önemli halk sağlı̆g 1 sorunlarından birisidir (1). Dünya genelinde 2016 yılında 18 yaş ve üstü yetişkinlerin \% 39'unun (1,9 milyar) fazla kilolu, \% 13'ünün ise (650 milyon) obez olduğu belirtilmektedir (2).

Beden imajı, bir kişinin bedeniyle ilgili algılarını, tutumlarını ve deneyimlerini ifade eder. Vücut ağırlığı algısı bu kavramın önemli bir parçasıdır (3). Vücut ağırlığı algısının doğruluğu, bireyin vücut ağırlığı algısının (normal kilolu, fazla kilolu veya düşük kilolu) gerçek vücut ağırlığıyla karşılaştırılması ile kavramsallaştırılır (4). Vücut ağırlı̆̆ının doğru bir şekilde algılanması, mevcut kilo durumunun farkındalığını sağlamakla birlikte optimal vücut ağırlığı kontrolü ve kilo ile ilişkili hastalıkların önlenmesi için gereklidir $(5,6)$. Ancak son yıllarda obezitenin bir halk sağllğı sorunu olduğunu gündeme getirmek için gösterilen çabalara rağmen, kendisini fazla kilolu/obez olarak algılayan obez yetişkin oranlarının azaldığı, önemli bir kısmının kilo durumlarını hafife aldıkları ve kendilerini olduklarından daha sağlıklı bir kiloda düşündükleri öne sürülmektedir $(4,7-11)$. Yedi y1llık izlem çalışmasında kendilerini kilolu olarak algılayan bireylerin zaman içinde olumlu sağlık algılarının azaldığı, daha fazla fizyolojik sorunlar (kardiyolojik, metabolik ve enflamatuvar vb.) ve depressif semptom yaşadıkları belirlenmiştir (12). Fazla kilolu bireylerin vücut ağırlık durumlarını doğru bir şekilde belirleyememesi, etkisiz kilo yönetimi ve yaşam kalitesinin olumsuz etkilenmesi açısından ciddi risk faktörleri olarak vurgulanmaktadır (13-15). Yapılan araştırmalarda hastalık farkındalığının bozulması ya da fazla kilolu/obez olduğunu kabul etmeme durumunun sağlıklı yaşam tarzı değişikliklerine bir engel olduğu, negatif klinik sonuçlara katkıda bulunduğu ve sağlk kurumuna başvuru oranları ile ilişkili olduğu gösterilmiştir (15-17).

Fazla kilolu ve obez yetişkinlerde hastalık farkındalığının arttırılması, tedaviye başlama ve uyumu kolaylaştırabilir, uzun dönemde obezite ile ilişkili morbidite ve mortalitenin azalmasına, yaşam kalitesinin artmasına katkı sağlayabilir $(7,14,16)$. Fazla kilolu ve obez yetişkinlere farkındalığın kazandırılmasında öncelikle doğru tanılama yapılması gerekir. Doğru tanılama için geçerli ve güvenilir tanılama araçlarına gereksinim vardır. Subjektif hastalık farkındalı̆̆ını değerlendiren, farklı hastalıklara ve obeziteye ilişkin ölçme araçları bulunmaktadır $(18,19)$. Buna karşın yetişkinlerde sağlıkla ilgili semptomları ve sonuçlarını değerlendiren, subjektif obezite farkındalığına yönelik, Türk toplumuna özgü bir değerlendirme aracına rastlanmamıştır. Bu çalışmanın amacı Gerretsen ve ark. (2018) tarafından geliştirilen Obezite Farkındalığı ve İçgörü Ölçeğinin (OFİ Ölçeği) (OASIS: The Obesity Awareness and Insight Scale) Türkçeye ve Türk kültürüne uyarlanarak geçerlilik ve güvenirlik çalışmalarının yapılmasıdır.

\section{Gereç ve Yöntem}

Metodolojik tipte tasarlanan bu araştırma örneklemi için iki grup kullanılmıştır. Birinci grup İzmir ili merkez ilçesinde yer alan bir eğitim ve araştırma hastanesinin endokrinoloji ve metabolizma hastalıkları polikliniğine (Perşembe günleri) başvuran hastalardan oluşmuştur. İkinci grup merkez ilçede yer alan bir eğitim aile sağlığı merkezine haftanın üç günü 8:00-17:00 saatleri arasında başvuran bireylerden oluşmuştur. Araştırmaya dahil edilme kriterleri her iki grup içinde 18 yaş ve üstünde olma, okuma yazma bilme, BKİ'sinin
25 ve üzerinde olması, işitme problemi ve akut psikiyatrik problemi olmama, araştırmaya katılmayı kabul etmedir. Araştırmada iki farklı örneklem grubuna yer verilmesinin amacı hem birinci hem ikinci basamağa başvuran, farklı sosyodemografik özelliklere sahip bireylerin görüşlerini yansıtabilmektir. Geçerlilik-güvenirlik çalışmalarında örneklem sayısının belirlenmesinde ölçek madde sayısının 5 - 10 katı ve tanımlayıcı değişken sayısının 10 katı kadar örneklem alınması önerilmektedir $(20,21)$. Bu öneriler doğrultusunda anket maddelerinin ve ölçülen değişken sayısının 20 katına denk gelen ve Eylül 2018- Şubat 2019 tarihleri arasında ulaşılabilen toplam 165 birey örneklemi oluşturmuştur. Araştırma kapsamındaki örneklemin \%57,6’ s1 (95 kişi) endokrin polikliniğine, \% 42,4' ü (70 kişi) aile sağlığı merkezine başvuran bireylerden oluşmuştur.

\section{Veri toplama araçları:}

Görüşme Formu: Bireylerin yaş, cinsiyet, eğitim durumunu belirlemeye yönelik üç sorudan oluşmaktadır.

Obezite Farkındalığı ve İçgörü Ölçeği (OFİ Ölçeği): Ölçeğin orijinal ad1 "OASIS: The Obesity Awareness and Insight Scale" dir (www. illnessawarenessscales.com) (16). Ölçek hastalık farkındalığı modeline dayanarak geliştirilmiştir. Modelin alanlarına göre sınıflandırılan ölçek tek boyutlu olup dört alanı kapsamaktadır. Bu alanlar: semptomların katkılarının farkındalı̆̆ı (madde 1), genel hastalık farkındalığ (madde $2,4,7$ ), tedavi gereksinimi farkındalığı (madde 3,5,8), negatif sonuçların farkındalığı (madde 6). Ölçeğin 4. ve 5. maddeleri ters kodlanarak değerlendirilmektedir. Orjinal ölçek geliştirme çalışmasında modelin alt alanları dikkate alınarak doğrulayıcı faktör analizi uygulanması, örneklemin küçük olması ve toplam madde sayısının az olması nedeniyle mümkün olmamıştır. Ölçeğin ilk bölümünde bireye ait vital / laboratuvar bulgularını sorgulayan altı, sağlıkla ilgili deneyimlerini sorgulayan ve evet hayır şeklinde yanıtlanan on soru bulunmaktadır. İkinci bölümde sekiz sorudan oluşan yedili likert tipinde yanıtlanan ölçek maddeleri yer almaktadır. Son bölüm puanlama bölümüdür. Ölçeğin orijinal Cronbach alpha değeri 0,89'dur (16).

Veri toplama araçları, G.U ve G.A.K tarafından örneklem grubundaki bireylere yüz yüze görüşme yöntemi ile uygulanmıştır. Endokrin polikliniğinde perşembe günleri, aile sağlığ merkezinde bir hafta pazartesi- çarşamba-cuma günleri, diğer hafta salı-perşembe günleri olacak şekilde 08.00-17.00 saatleri arasında toplanmıştır. Test-tekrar testler için bireylerle 15 gün sonra tekrar görüşülmüş, tekrar formları doldurulmuştur.

\section{Etik Uygulamalar}

Girişimsel Olmayan Araştırmalar Etik Kurulu'ndan etik izin (2018/ Karar no: 283) ve her iki kurumdan kurum izni alınmıştır. Veri toplama işleminden önce bireylere araştırmanın amacı hakkında bilgi verilerek yazılı onamları alınmıştır. Formlara isim yazılmamıştır. Sadece test-re-test formları için her iki birimdeki ilk 15'er, toplam 30 bireye rumuz verilmiştir. İki hafta sonra bireylere telefon ile ulaşılarak formlar yeniden doldurulmuştur.

\section{İstatistiksel Yöntem}

Araştırmada elde edilen veriler SPSS 25®) (Statistical Package for Social Sciences) paket programı kullanılarak analiz edilmiştir. Sayısal veriler için ortalama, minimum ve maksimum değerleri, 
kategorik verilerde ise sayı ve yüzde hesaplamaları kullanılmıştır. Güvenirlik analizleri için değişmezlik ve iç tutarlılık analiz yöntemlerinden yararlanılmıştır. Yararlanılan bu yöntemler 1) madde toplam puan korelasyonu (madde güvenilirliği için), 2) Cronbach alpha (homojenliğin belirlenmesi için), 3)test-tekrar test ve pearson momentler çarpımı korelasyonudur (ölçeğin zamana karşı değişmezliği). Madde toplam puan korelasyonu kriteri olarak 0,30 ve üzeri alınmıştır $(22,23)$. Ölçeğin kapsam geçerliği için Kapsam Geçerlilik İndeksi (KGI), faktör yapı geçerliği için Açımlayıcı Faktör Analizi kullanılmıştır. Verilerin faktör analizine uygunluğunu belirlemede Kaiser-Meyer -Olkin (KMO) değeri ile Barlett's testi uygulanmıştır $(21,24)$. Faktör analizinin hesaplanmasında varimax eksen döndürme yöntemi de kullanılmıştır. İstatistiksel anlamlıl1k düzeyi $\% 95$ güven aralığında $p<0,05$ olarak kabul edilmiştir.

\section{Bulgular}

Araştırmaya 165 fazla kilolu ve obez birey katılmıştır. Bireylerin

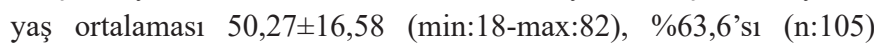
kadındır. Bireylerin Beden Kütle İndeksi (BKI) ortalaması 35,42 \pm 7,20 (min:25,5-max:66,7) dir. Sistolik kan basınc1 ortalamas 133,19 $\pm 20,37 \mathrm{mmHg}$ (min:90-max:200), diyastolik kan basinc1

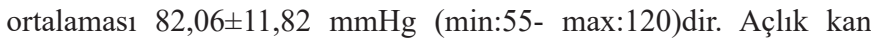
şekeri (AKŞ) ölçüm değerine ulaşılabilen 58 bireyin AKŞ ortalaması 121,26 $\pm 39,93$ (min:70- max:230) tür. Onaltı bireyin HgA1c değeri ortalaması ise 6,68 $\pm 2,20$ (min:4,6- max:13) dir (Tablo 1).

Tablo 1. Katılımc1ları tanıtıcı bilgiler

\begin{tabular}{|c|c|c|}
\hline ÖZELLIKKLER & Sayı (n) & Yüzde (\%) \\
\hline \multicolumn{3}{|l|}{ Yaş grubu } \\
\hline$\leq 49$ yaş & 72 & 43,6 \\
\hline 50-64 yaş & 51 & 30,9 \\
\hline$\geq 65$ yass & 42 & 25,5 \\
\hline \multicolumn{3}{|l|}{ Cinsiyet } \\
\hline Kadın & 105 & 63,6 \\
\hline Erkek & 60 & 36,4 \\
\hline \multicolumn{3}{|l|}{ Eğitim durumu } \\
\hline $\begin{array}{l}\text { Okur-yazar değil/okur- } \\
\text { yazar }\end{array}$ & 16 & 9,7 \\
\hline İlkokul & 49 & 29,7 \\
\hline Ortaokul & 23 & 13,9 \\
\hline Lise & 37 & 22,4 \\
\hline Üniversite ve üzeri & 40 & 24,2 \\
\hline \multicolumn{3}{|l|}{ BKİ Sinıfi } \\
\hline Fazla kilolu & 39 & 23,6 \\
\hline I. derece obez & 54 & 32,7 \\
\hline II. derece obez & 32 & 19,4 \\
\hline III. derece obez & 40 & 24,2 \\
\hline \multicolumn{3}{|l|}{ HbA1c (n:16) } \\
\hline$<5,00$ & 3 & 18,8 \\
\hline $5,00-6,49$ & 6 & 37,4 \\
\hline$\geq 6,50$ & 7 & 43,8 \\
\hline Toplam & 165 & 100 \\
\hline
\end{tabular}

Bireylerin \%84,85'i (n:140) tablo 2'de sayllan obezite ile ilişkil sağlık sorunlarından en az birini deneyimlemiştir.
Tablo 2. Bireylerin sağlıkları ile ilgili deneyimleri

\begin{tabular}{|ll|c|c|}
\hline & & $\begin{array}{c}\text { Sayı } \\
\text { (n) }\end{array}$ & $\begin{array}{c}\text { Yüzde } \\
\text { (\%) }\end{array}$ \\
\hline A. & $\begin{array}{l}\text { Özellikle hareket ettiğinizde (yürüyüş, koşma, merdiven } \\
\text { çıkma, vb.) devamlı olarak nefes almakta zorluk çekiyor } \\
\text { musunuz? }\end{array}$ & 97 & 58,8 \\
\hline B. & Geceleri devamlı olarak uyumakta zorluk çekiyor musunuz? & 64 & 38,8 \\
\hline C. & Devamı olarak nefessiz kalarak uyanıyor musunuz? & 25 & 15,2 \\
\hline D. & Devamı olarak yorgun musunuz? & 104 & 63,0 \\
\hline E. & $\begin{array}{l}\text { Kendinizi sürekli olarak keyifsiz ya da depresyonda } \\
\text { hissediyor musunuz? }\end{array}$ & 82 & 49,7 \\
\hline F. & Çevrenizdeki diğer insanlardan kaçınıyor musunuz? & 44 & 26,7 \\
\hline G. & Devamlı olarak acınız ya da ağrınız var mı? & 61 & 37,0 \\
\hline H. & $\begin{array}{l}\text { Özellikle hareket ederken (yürüyüş, koşma, merdiven çıkma, } \\
\text { vb.) sıklıkla göğïs ağrınız oluyor mu? }\end{array}$ & 45 & 27,3 \\
\hline I. & Bazen idrar kaçırdığınız oluyor mu? & 42 & 25,5 \\
\hline
\end{tabular}

*Birden fazla cevap verilmiştir.

\section{Ölçeğin Dil ve Kapsam Geçerliliği Bulguları}

Ölçeğin dil geçerliliği için iki uzman tarafından Türkçe'ye çeviri, iki uzman tarafından İngilizce'ye geri çeviri yapılmıştır. Kapsam geçerliliği için beş uzmandan (iki akademisyen hemşire, iki aile hekimi uzmanı, bir dahiliye uzmanı) görüş alınmıştır. Ölçek maddeleri için kapsam geçerlilik indeksinin hesaplanmasında Davis tekniği (1992) kullanılmıştır. Buna göre uzmanlardan maddeleri (a) "uygun", (b) "madde hafifçe gözden geçirilmeli", (c) "madde ciddi olarak gözden geçirilmeli" ve (d) "madde uygun değil" şeklinde dörtlü olarak değerlendirmeleri istenmiştir. Tekniğe göre (a) ve (b) seçeneğini işaretleyen uzmanların sayısı toplam uzman sayısına bölünerek maddeye ilişkin "kapsam geçerlilik indeksi”" elde edilmiştir. Tüm ölçek maddeleri için KGİ değeri 1,00 olarak belirlenmiştir.

\section{Yapı Geçerliği}

Ölçeğin yap1 geçerliliği faktör analizi ile değerlendirilmiştir. Örneklemin faktör analizi için yeterli olup olmadığı Kaiser-MeyerOlkin (KMO) ve Barlett testi ile belirlenmiştir. Buna göre ölçeğin KMO örneklem yeterliliği ölçütü karşılanmış ve 0,89'dur. Barlett's testine göre ölçek maddeleri birbiriyle yüksek korelasyon göstermiştir $\left(\chi^{2}=468,137 ; \mathrm{p}=0,0001\right)$.

Ölçeğin faktör yapısı açıklayıcı faktör analizi temel bileşenler yöntemi ile incelenmiştir. Özdeğeri 1 'in üzerinde olan tek faktör belirlenmiştir. Bu faktörün öz değeri 4,24, açıkladığı varyans \%52,98'dir. OFİ madde toplam puan ortalamaları ve korelasyon katsayıları ile faktör yükleri tablo 4 ve tablo 5 'te verilmiştir. Ölçek maddelerinin faktör yüklerinin 0,519-0,837 arasında değiştiği görülmüştür (Tablo 4).

\section{Ölçeğin Güvenilirliği}

\section{İç tutarlıık analizi}

Ölçeğin iç tutarlılık katsayısı (Cronbach alpha) 0,86'dır. Ölçeğin her bir maddesi için madde birakma tekniği ile madde toplam korelasyonları ve Cronbach alfa katsayıları hesaplanmış, Cronbach Alpha katsayılarının 0,832 ile 0,870 arasında değiştiği görülmüştür.

\section{Değişmezlik analizi}


Ölçeğin güvenilirliği aralıklı test tekrar test yöntemi ile ölçülmüştür. Örneklem grubundan araştırmanın yürütüldüğü merkezlere başvuran ilk 15 'er, toplam 30 bireye iki hafta sonra telefon yolu ile ulaşılarak ölçek tekrar uygulanmıştır. Bireylerin ilk ve ikinci uygulamadan aldıkları puan arasındaki korelasyon katsayısı 0,79’ dur $(\mathrm{p}<0,05)$.

Araştırmaya katılanların anket maddelerine verdikleri tepkilerin eşit olup olmadığını test etmek için Hotelling $\mathrm{T}^{2}$ testi kullanılmıştır. Yapılan analiz sonucu, ortalamaların farklı olduğu (Hotelling $\mathrm{T}^{2}=$ $17,99, \mathrm{p}=0,0001$ ), bireylerin maddeleri cevaplamakta farklı yaklașım gösterdikleri belirlenmiştir.

Bireylerin OFI toplam puan ortalaması $6,87 \pm 2,48^{\prime}$ dir (Tablo 3) Cinsiyete ve eğitim düzeyine göre bireylerin OFI toplam puan ortalaması değişmemektedir ( $\mathrm{p}>0,05)$. BKİ sınıfına göre bireylerin OFI toplam puan ortalamaları arasında fark vardır (KW:61,77; $\mathrm{p}=0,000)$ ve BKİ arttıkça ölçek toplam puan ortalaması da artmaktadır (OFI Toplam Puan Ortalamalar1- Fazla kilolu: 4,93 $\pm 2,21$; I.derece obez: 6,30 $\pm 2,25$; II.derece obez: 8,16 $\pm 1,79$; III.derece obez: $8,49 \pm 1,85$ ) .Yaş guruplarına göre OFİ toplam puan ortalamaları arasında fark vardır (KW:16,08; $\mathrm{p}=0,000)$ ve yaş azaldıkça ölçek puan ortalaması artmaktadır (OFI Toplam Puan Ortalamaları: $\leq 49$ yaş: 7,58 $\pm 2,21$ 50-64 yaş: $6,92 \pm 2,11 ; \geq 65$ yaş: $5,57 \pm 2,83)$.

Tablo 3. Bireylerin Obezite Farkındalığı ve İçgörü Ölçek Puanı (n:165)

\begin{tabular}{|l|l|l|}
\hline ÖLÇEK VE ALT ALANLARI & $\mathbf{X} \pm \mathbf{S S}$ & Medyan (Min-Maks.) \\
\hline OFI Toplam Puan Ortalaması & $6,87 \pm 2,48$ & $7,33(0-10)$ \\
\hline $\begin{array}{l}\text { OFİ Genel Hastalık Farkındalığı } \\
\text { (2.,4.,7. maddeler) }\end{array}$ & $7,08 \pm 2,73$ & $7,67(0-10)$ \\
\hline $\begin{array}{l}\text { OFI Semptomları Katkılarını } \\
\text { Farkındalığı (1. madde) }\end{array}$ & $6,50 \pm 3,67$ & $8,00(0-10)$ \\
\hline $\begin{array}{l}\text { OFİ Tedavi Gereksinimi } \\
\text { Farkındalığı (3., 5., 8. maddeler) }\end{array}$ & $6,11 \pm 2,72$ & $6,67(0-10)$ \\
\hline $\begin{array}{l}\text { OFİ Olumsuz Sonuçların } \\
\text { Farkındalığı (6. madde) }\end{array}$ & $7,91 \pm 2,86$ & $10,00(0-10)$ \\
\hline
\end{tabular}

\section{Tartışma}

$\mathrm{Bu}$ araştırmada fazla kilolu/obez bireylerin öz farkındalık ve içgörülerini belirlemek için geliştirilmiş olan Obezite Farkındalığı ve İçgörü Ölçeğinin Türkçeye uyarlanması amacıyla geçerlilik ve güvenilirlik analizleri yapılmıştır.

Bir aracın çalışılan yapının özelliklerini ölçebilme yeteneği olarak tanımlanan geçerliliğin kapsam, yapı ve ölçüt olmak üzere üç yaygın türü bulunmaktadır $(20,25,26)$. Kapsam geçerliği diğer geçerlilik türleri için bir ön koşul olduğundan ölçek geliştirme sırasında birinci öncelik verilmelidir (25). Araştırmada ölçeğin kapsam geçerliliği için beş uzmandan alınan önerilere göre ilk bölümde bulunan sağlik sorunları ile ilgili dört soru ve ikinci bölümdeki dört ölçek maddesi (3., 4., 6. ve 8. madde) yeniden düzenlenmiştir. Davis tekniği kullanılarak elde edilen kapsam geçerlilik indeksinin 1,00 olduğu belirlenmiştir. KGİ için 0,78 ve üzeri değerlerin ve 0,80 üzeri değerlerin kabul edilebilir olduğunu belirten kaynaklar bulunmaktadır (23,26-28). Buna göre bu araştırmadaki ölçekten elde edilen KGİ değeri, ölçekteki her bir maddenin ölçülmek istenen kavramı ölçtüğünü, farklı kavramları barındırmadığını ve kapsam geçerliliğinin olduğunu göstermiştir.

Geçerliliğin diğeryaygın türü olan yapı geçerliliği ile bir ölçüm aracının doğrudan gözlenemeyen ancak kuramsal olarak açılanan soyut bir kavramı ya da davranışı ne derece doğru ölçebildiği değerlendirilir $(20,29,30)$. Bu araştırmada ölçeğin yapı geçerliliği faktör analizi ile değerlendirilmiştir. Faktör analizi hem ölçeğin bütünlügünü test etmekte, hem de konuyla ilişkisi olmayan maddelerin arındırılmasına yardımcı olmaktadır $(20,30)$. KMO ve Barlett's testi örneklemin faktör analizi için yeterli olduğunu göstermiştir. Yapılan açımlayıcı faktör analizinde ölçeğin tek boyutlu olduğu belirlenmiştir. Varimax eksen döndürme yöntemi uygulandıktan sonra, belirlenen tek faktörün toplam varyansın $(\% 52,98) \% 40$ 'dan fazlasını açıklaması kriterini karşıladığ 1 görülmüştür (24). Ölçek maddelerinin faktör yüklerinin 0,30 'un üzerinde olduğu $(0,519-0,837)$ ve iyi ayırt ediciliğe sahip olduğu, tüm maddelerin yapı geçerliliğini desteklediği söylenebilir $(23,24)$. Orjinal ölçekte de benzer şekilde tek boyut bulunmaktadır (16). Ancak çalışmada, ölçeğin bir hastalık farkındalığ 1 modeline dayanarak geliştirildiği, bu modele göre kuramsal olarak dört alan belirlendiği (genel hastalık farkındalığı, semptomların katkılarının farkındalığı, olumsuz sonuçların farkındalığı ve tedavi gereksinimi farkındalığı) belirtilmiştir (16). Orijinal ölçek çalışmasında bu alanların, örneklemin küçük olması ve ölçekte madde sayısının az olması nedeniyle doğrulayıcı faktör analizi ile sınanamadığı ifade edilmiştir (16). Bu araştırmada da ölçek madde sayısının azlığı nedeniyle doğrulayıcı faktör analizi yapılamamış, ancak orijinal ölçekte belirtilen alanlara yer verilmiştir. İleride yapılacak ölçek geliştirme çalışmalarında, bu ölçek de var olan alt alanların boyutlandırılarak doğrulayıcı faktör analizi yapılması önerilebilir.

Ölçeğin güvenirliği değişmezlik, iç tutarlılık ve madde toplam puan korelasyonu analizleri ile belirlenmiştir. Değişmezlik bir ölçme aracının farklı zamanlarda yapılan her uygulamada tutarlı sonuçlar verebilme özelliğidir (20,31). Ölçeğin değişmezliği bu araştırmada aralıklı test tekrar test yöntemi ile değerlendirilmiştir. Örneklemden seçilen 30 bireye 15 gün arayla uygulanan iki ölçek değerleri arasında Pearson Momentler Çarpımı korelasyonu hesaplanmış ve yüksek korelasyon olduğu görülmüştür. Sonuçta bireylerin her iki uygulamada elde edilen ortalama ve standart sapma değerleri benzerdir. Orijinal ölçekte test tekrar test korelasyonu 0,76'dır (16). Orjinal ölçek ile benzer şekilde OFI'nin değişmezlik gücünün yeterli olduğu söylenebilir.

İç tutarlılık, bir ölçekteki tüm maddelerin aynı kavramı veya yapıyı ne ölçüde ölçtüğünü açıklar. İç tutarlılığın belirlenmesinde en yaygın kullanılan yöntemlerden biri olan Cronbah's alpha güvenilirlik katsayıs1, Lee Cronbach tarafindan 1951 yılında geliştirilmiştir; 0 ile 1 arasında bir değer alır (32). Kabul edilebilir Cronbach's alfa değerlerinin 0.70 ile 0.95 arasında değiştiğini bildiren yayınlar bulunmaktadır $(33,34)$. Buna göre Cronbach alfa's1 0,86 olarak hesaplanan OFI'nin yüksek iç tutarlılık gösterdiği, her maddesinin aynı tutumu ölçtüğü söylenebilir. Orijinal ölçeğin Cronbach alfa $(0,89)$ değeri de iç tutarlılığının iyi olduğunu göstermektedir. Maddelerin en düşük toplam madde korelasyonu değerinin 0,428 (madde 5), en yüksek değerin ise 0,746 (madde 7) olduğu belirlenmiştir. Korelasyon değeri 0,20 nin altında madde bulunmadığı için ölçekten hiçbir madde çıkarılmamıştır (35). Bu araştırmada güvenilirlik analizleri kapsamında Hotelling $\mathrm{T}^{2}$ testi sonucuna göre bireylerin verdikleri cevapların tutarlı ve güvenilir olduğu söylenebilir. 
Bireylerin ölçekten aldığı puanların sosyodemografik özelliklere ve BKI'ye göre değişimi değerlendirilmiştir. Gerretsen ve ark.'nın (2018) çalışması ile benzer şekilde OFİ toplam puan ortalamasının cinsiyet ve eğitim düzeyine göre değişmediği, ancak bireylerin BKİsi arttıkça ölçek toplam puan ortalamasının da arttığı, en yüksek obezite farkındalığının III. Derece obez grupta olduğu görülmüştür. Gerretsen ve ark.'nın (2018) çalışmasında yaşa göre obezite farkındalığının değişmediği belirtilmekte, ancak bu çalışmada bireylerin yaşı azaldıkça ölçek puan ortalaması artmaktadır $(\mathrm{p}<0,05)$. En yüksek obezite farkındalığına sahip olan grubun 49 yaş altı olduğu görülmüştür. Buna göre öznel obezite farkındalığı üzerinde cinsiyet ve eğitim düzeyinin etkisi olmadığı, ancak BKİ'deki önemli artışların obezite farkındalığını artırdığı söylenebilir. Artan yaşla birlikte obezite farkındalığındaki azalma ise azalan yaşam beklentisi ve umudu ile ilişkili olabilir.

Sonuç olarak, Obezite Farkındalığı ve İçgörü Ölçeğinin fazla kilolu/obez bireylerin obezite farkındalıklarını belirlemek amacıyla kullanılabilecek geçerli ve güvenilir bir ölçme aracı olduğu saptanmışırı. Basit ve anlaşılır, kısa zamanda uygulanabilir olan bu ölçek hem birinci basamak hem de ikinci basamak sağllk hizmeti sunan kurumlarda farklı ekip üyeleri tarafindan kullanılabilir niteliktedir. Ölçeğin farklı araştırma tasarımlarında yürütülecek çalışmalar için kullanılması önerilir.

Tablo 4. OFİ Türkçe Versiyonunun Madde Toplam Puan Ortalamaları, Korelasyon Katsayıları ve Faktör Yükleri

\begin{tabular}{|c|c|c|c|c|c|c|c|c|}
\hline \multicolumn{2}{|c|}{ Maddeler } & \multirow{2}{*}{$\begin{array}{c}\text { Ortalama } \\
6,51\end{array}$} & \multirow{2}{*}{$\begin{array}{l}\text { SS } \\
3,67\end{array}$} & \multirow{2}{*}{$\begin{array}{c}\text { Madde çıktığında } \\
\text { ölçek ortalaması } \\
49,24\end{array}$} & \multirow{2}{*}{$\begin{array}{c}\text { Madde çıktığında } \\
\text { ölçek varyansı }\end{array}$} & \multirow{2}{*}{$\begin{array}{c}\begin{array}{c}\text { Madde toplam } \\
\text { korelasyonu }\end{array} \\
\text {,662 }\end{array}$} & \multirow{2}{*}{$\begin{array}{c}\begin{array}{c}\text { Madde çıttığında } \\
\text { ölçek Cronbach } \\
\text { Alpha katsayısı }\end{array} \\
, 508\end{array}$} & \multirow{2}{*}{$\begin{array}{r}\text { Faktör } \\
\text { yükü }\end{array}$} \\
\hline & $\begin{array}{l}\begin{array}{l}\text { Yaşadıklarım fazla kilolu ya da } \\
\text { kaynaklanıyor }\end{array} \\
\text { kayez olmamdan }\end{array}$ & & & & & & & \\
\hline 2. & Aşırı miktarda vücut yağım var & 7,51 & 2,86 & 48,23 & 288,06 & ,717 & 600 & 813 \\
\hline 3. & $\begin{array}{l}\text { Diyetimi düzenlemek ve egzersiz miktarımı arttırmak } \\
\text { için sağıkıı yaşam biçimi değişiklikleri yapmaya veya } \\
\text { sürdürmeye ihtiyacım var }\end{array}$ & 7,86 & 2,78 & 47,89 & 303,71 & ,561 & 853 & ,657 \\
\hline 4. & Vücut ağırlığım sağlıkı bir seviyede & 7,02 & 3,50 & 48,72 & 284,49 &, 584 & 851 & 687 \\
\hline 5. & $\begin{array}{l}\text { Şu anki yaşam biçimimi güvenli bir şekilde sürdürebilirim } \\
\text { (örneğin şu anda yaptığım gibi yeme, içme, egzersiz). }\end{array}$ & 4,94 & 3,75 & 50,80 & 296,56 & ,428 & ,870 & ,519 \\
\hline 6. & $\begin{array}{l}\text { Vücut ağırlı̆ı̆m olumsuz sağlık sonuçlarına sebep oluyor } \\
\text { ya da olabilir. (örneğin yüksek kolesterol, yüksek tansiyon, } \\
\text { diyabet, kalp hastalığı, depresyon vb.) }\end{array}$ & 8,19 & 2,68 & 47,55 & 303,47 & ,591 & ,851 & ,703 \\
\hline 7. & $\begin{array}{l}\text { Ben fazla kilolu ya da obezim (Beden Kütle İndeksinin } \\
25 \text { 'ten yüksek olması= fazla kilolu; Beden Kütle İndeksinin } \\
\text { 30'dan yüksek olması=obez) }\end{array}$ & 7,53 & 3,20 & 48,21 & 276,21 & ,746 & ,832 & 837 \\
\hline 8. & Kilo vermek için tedaviye ihtiyacım var & 6,18 & 4,03 & 49,56 & 259,41 & 693 & ,516 & ,789 \\
\hline
\end{tabular}

Tablo 5. OFİ ve Alt Alanların Korelasyonları

\begin{tabular}{|c|c|c|c|c|c|}
\hline & OFİ Toplam Puan Ortalaması & $\begin{array}{c}\text { OFİ Semptomların } \\
\text { Katkılarının Farkındalığı }\end{array}$ & $\begin{array}{l}\text { OFİ Genel Hastalık } \\
\text { Farkındalığı }\end{array}$ & $\begin{array}{l}\text { OFİ Tedavi Gereksinimi } \\
\text { Farkındalığı }\end{array}$ & $\begin{array}{c}\text { OFİ Olumsuz Sonuçların } \\
\text { Farkındalığı }\end{array}$ \\
\hline $\begin{array}{l}\text { OFİ 1. Madde (OFİ } \\
\text { Semptomları Katkılarının } \\
\text { Farkındalığı) }\end{array}$ & $0,85^{*}$ & - & $0,64^{*}$ & $0,56^{*}$ & $0,43^{*}$ \\
\hline OFi 2. madde & $0,76^{*}$ & $0,64^{*}$ & $0,83^{*}$ & $0,59^{*}$ & $0,54 *$ \\
\hline OFI 3. madde & $0,57^{*}$ & $0,34^{*}$ & $0,50^{*}$ & $0,67^{*}$ & $0,42^{*}$ \\
\hline OFI 4. madde & $0,65^{*}$ & $0,40^{*}$ & $0,82^{*}$ & $0,52^{*}$ & $0,49^{*}$ \\
\hline OFI 5. madde & $0,58^{*}$ & $0,34^{*}$ & $0,43^{*}$ & $0,79 *$ & $0,26^{*}$ \\
\hline $\begin{array}{l}\text { OFİ 6. Madde (OFİ } \\
\text { Olumsuz Sonuçların } \\
\text { Farkındalığı) }\end{array}$ & $0,72^{*}$ & $0,43^{*}$ & $0,63^{*}$ & $0,48^{*}$ & - \\
\hline OFI 7. madde & $0,81^{*}$ & $0,64^{*}$ & $0,87^{*}$ & $0,62^{*}$ & $0,63^{*}$ \\
\hline OFI 8. madde & $0,76^{*}$ & $0,61^{*}$ & $0,65^{*}$ & $0,81^{*}$ & 0,46 \\
\hline $\begin{array}{l}\text { OFI Tedavi Gereksinimi } \\
\text { Farkındalığı (3., 5., } 8 . \\
\text { maddeler) }\end{array}$ & $0,84^{*}$ & $0,56^{*}$ & $0,69^{*}$ & - & $0,49^{*}$ \\
\hline $\begin{array}{l}\text { OFİ Toplam Puan } \\
\text { Ortalaması }\end{array}$ & - & $0,85^{*}$ & $0,87^{*}$ & $0,84^{*}$ & $0,72^{*}$ \\
\hline
\end{tabular}

$* \mathrm{p}<0,01$ 


\section{Kaynaklar}

1.Obesity Fact Sheet - STOP Obesity Alliance. Available from: http://stopobesityalliance org/facts-and-resources/obesity-fact-sheet/ Accessed: Jully 5, 2018.

2.World Health Organization. Obesity and overweight. Available from: http://www.who int/news-room/fact-sheets/detail/obesity-and-overweight Accessed: Jully 4, 2018.

3.Wong MMC, Tso S, Lui SSY. Accuracy of body weight perception and figure satisfaction in young adults with psychotic disorders in Hong Kong. Hong Kong J Psychiatry. 2009;19:107-11.

4.Liu S, Fu MR, Hu SH, Wang VY, Crupi R, Qiu JM, et al. Accuracy of body weigh perception and obesity among chinese americans. Obes Res Clin Pract. 2016;10:48-56.

5.Monteagudo Sánchez C, Dijkstra SC, Visser M. Self-perception of body weight status in older Dutch adults. J Nutr Heal Aging. 2015;19:612-8.

6.Tock WL, Tung W-C, Holston EC, Hsu Y-W. Bodyweight misperception by Chinese American females influenced by cultural and social ideals: implication for home health care. Home Health Care Manag Pract. 2019; 1084822319893993.

7.Johnson F, Beeken RJ, Croker H, Wardle J. Do weight perceptions among obese adults in Great Britain match clinical definitions? Analysis of cross-sectional surveys from 2007 and 2012. BMJ Open. 2014;4:e005561.

8.Jayawardena R, Punchihewa P, Ranathunga I, Lokunarangoda N, Pathirana AK, Santharaj WS. Body weight perception among Sri Lankan cardiac patients. BMC Obes. 2016;3:1-7.

9.Gao C, Lv X, Yin Y, Song Y, Zhang P, Wang R, et al. Perceptions and behaviours towards high body weight among adults in Northeast China. Public Health Nutr. 2017;20:1557-63.

10.Brandão I, Martins MJ, Monteiro R. Metabolically healthy obesity-Heterogeneity in definitions and unconventional factors. Metabolites. 2020;10:1-29.

11.Robinson E, Oldham M. Weight status misperceptions among UK adults: The use of self-reported vs. measured BMI. BMC Obes. 2016;3:1-6.

12.Daly M, Robinson E, Sutin AR. Does knowing hurt? perceiving oneself as overweight predicts future physical health and well-being. Psychol Sci. 2017;28(7):872-81.

13.Romano E, Haynes A, Robinson E. Weight Perception, Weight Stigma Concerns, and Overeating. Obesity. 2018;26:1365-71.

14.Heard C, Scuffham PA, Ratcliffe J, Whitty JA. The association between misperceptions around weight status and quality of life in adults in Australia. Health Qual Life Outcomes. 2017;15:53.

15.Park Y-J, Lee S-J, Shin N-M, Shin H, Jeon S, Lee J, et al. Application and Effect of Mobiletype-Bone Health Intervention in Korean Young Adult Women with Low Bone Mass: A Randomized Control Trial. BMJ Open. 2017;7: e016098.

16.Gerretsen P, Kim J, Shah P, Quilty L, Balakumar T, Caravaggio F, et al. OASIS: The obesity awareness and insight scale. Obes Med. 2018;9:38-44.

17.Kim Y, Austin SB, Subramanian S V., Kawachi I. Body weight perception, disordered weight control behaviors, and depressive symptoms among Korean adults: The Korea National Health and Nutrition Examination Survey 2014. PLoS One. 2018;13:e198841.

18.Köse EÖ, Gül Ş, Keskin B. Ortaöğretim öğrencilerinin madde bağımlılığı ile ilgili farkındalık ve bilgi düzeylerinin incelenmesi. Bağımlılık Derg. 2017;18:8-15.

19.Kafkas ME, Özen G. Obezite farkındalık ölçeği'nin (OFÖ) Türkçeye uyarlanması: bir geçerlik ve güvenirlik çalıșması. J Phys Educ Sport Sci. 2014;1:1-15.

20.Esin MN. Veri toplama yöntem ve araçları \& veri toplama araçlarının güvenirlik ve geçerliği. In: Erdoğan S, Nahcivan N, Esin MN, ed. Hemşirelikte araştırma sürec, uygulama ve kritik. İstanbul: Nobel Tıp Kitabevleri, 2014;193-233.

21.Tavşancıl E. Tutumların ölçülmesi ve SPSS ile veri analizi. 5. Baskı. Ankara, Türkiye: Nobel Yayıncılık, 2014;19-51.

22.Büyüköztürk G. Sosyal bilimler için veri analizi el kitabı: istatistik, araștırma deseni, SPSS uygulamaları ve yorum. 20. Bask1. Ankara, Türkiye: Pegem Akademi, 2014.
23.Gözüm S, Aksayan S. Kültürlerarası ölçek uyarlaması için rehber II: psikometrik özellikler ve kültürlerarası karşılaştırma. HEMAR-G. 2003;5:3-14.

24.Çokluk Ö, Şekercioğlu G, Büyüköztürk G. Sosyal bilimler için çok değişkenli istatistik SPSS ve LISREL uygulamaları. 3. Baskı. Ankara, Türkiye: Pegem Akademi, 2014.

25.Zamanzadeh V, Ghahramanian A, Rassouli M, Abbaszadeh A, Alavi-Majd H, Nikanfar A-R. Design and implementation content validity study: development of an instrument for measuring patient-centered communication. J Caring Sci. 2015;4:165-78.

26.Rutherford-Hemming T. Content Validity Ratio. In: Frey B.B., ed. The SAGE encyclopedia of educational research, measurement, and evaluation. Thousand Oaks: SAGE Publications, 2018; 397-398.

27.Șencan H. Sosyal ve davranıșsal ölçümlerde güvenirlik ve geçerlilik. 1. Baskı. Ankara: Seçkin Yayıncılık, 2005.

28.Davis LL. Instrument review: getting the most from a panel of experts. Appl Nurs Res. 1992;5:194-7.

29.Ginty AT. Construct Validity. In: Encyclopedia of Behavioral Medicine. New York Springer, 2013;487-487.

30.Strauss ME, Smith GT. Construct validity: advances in theory and methodology. Annu Rev Clin Psychol. 2009;5:1-25.

31.Tang W, Cui Y, Babenko O. Internal consistency: do we really know what it is and how to assess it? J Psychol Behav Sci. 2014;2:205-20.

32.Tavakol M, Dennick R. Making sense of Cronbach's alpha. IJME; 2011;2:53-5.

33.Connelly LM. Cronbach's alpha. Medsurg nursing. 2011;20:45-47.

34.Bland JM, Altman DG. Statistics notes: Cronbach’s alpha. BMJ. 1997;314:572.

35.Öner N. Türkiye'de kullanılan psikolojik testler: bir başvuru kaynağı. 2. baskı. İstanbul: Boğaziçi Üniversitesi Yayınevi; 1996. 